The paper also gives further information concerning the Bajocian denudation, and with it is presented a map showing the areas of the different rocks upon which the Upper Trigonia-grit reposes non-sequentially. Notice is also taken of a water-bearing bed, and of its economic importance. Some remarks are made upon the ancient geography of the Cleeve Hill plateau in regard to streams. Their probable courses are marked upon a map.

3. "Pleistocene Plants from Casewick, Shacklewell, and Grays." By Clement Reid, Esq., F.L.S., F.G.S.

The plants from Casewick and Shacklewell were obtained by washing two lumps of clay in the collection of the late Sir Joseph Prestwich. The species are few and call for little remark, except that the climate was not Arctic. They are all common British forms.

The collection from Grays consists of leaves, already partly determined by Gaudin and Heer, though unpublished, and some lumps of clay, out of which the author washed a few seeds. The flora points clearly to a temperate climate and mild winters.

4. "An Explanation of the Claxheugh Section (Co. Durham)." By D. Woolacott, Esq., M.Sc. (Communicated by Professor G. A. Lebour, M.A., F.G.S.)

The section of which an explanation is offered in this communication occurs about two miles west of Sunderland, and has been noticed by Messrs. King and Howse and Professor Lebour. 'The base shows the Permian Yellow Sands, which are succeeded at the west end of the section by the Marl Slate, thin-bedded limestones, and at the top crystalline limestones without any trace of bedding. At the east end the Marl Slate and thin-bedded limestone are absent, and, except when a breccia intervenes, the crystalline limestone rests on the Yellow Sands, though the thin-bedded limestone and Marl Slate show no signs of thinning-out. There are also minor complications. The author suggests that the section may be explained by supposing that denudation occurred in a cavern, the root of which afterwards fell in, and that disturbances were also produced by "creep"-movements.

\title{
CORRESFONDENOE.
}

\section{THE ORIGIN OF THE GREY GNEISS OF ANGLESEY.}

Sir,--In the debate at the Geological Society on April 28, when my paper on the Grey Gneiss of Anglesey was read, some criticisms were offered by the Rev. J. F. Blake, to which, with your permission, I desire to make a brief reply. Had I enjoyed the good fortune to be present on the occasion, it would not be necessary for me thus to trouble you.

To save your valuable space, I will confine myself to one pointthe nature of the rock out of which the grey gneiss has been formed. This is a vital part of the question, and, if it be settled, much else will follow. In my paper I contended that the gneiss was originally 
a felsite. The Rev. J. F. Blake denied this. He admitted that "some eminent petrologists" had, on microscopic examination, pronounced the rock from which the gneiss has been formed to be a felsite; but he would not yield to their testimony. $\mathrm{He}$ had seen the rock in the field, and he "regretted" that these authorities had mado a mistake. It may seem a little presumptnous for $\mathrm{Mr}$. Blake to contest a determination made by three of the best petrographers in Europe; and we may suspect that if Ajax ventures to defy the lightning, Ajax will not do himself much good. Most people will consider that such an authoritative identification is absolutely decisive, and I, for one, assume it to be so. My main purpose in writing is, however, to point out that even the fieldevidence, which, in Mr. Blake's opinion, refutes the "eminent petrologists," is dead against him. Within a hundred yards of the critical section at $\mathrm{Y}$ Graig, in which the felsite passes into the gneiss, a rock which closely resembles the felsite and which also graduates into a similar gneiss, is seen to penetrate the diorite, which is more or less altered, in numerous veins, some of which are branched. Thus the microscope of the "eminent petrologists" and the eyes of the field-observer who knows where to look, lead to the same conclusion. Mr. Blake himself admits that the rock thus shown to be a felsite "passes by insensible gradations into the ordinary grey gneiss." He says that the "phenomenon is a purely local one." This is a mistake, as I can prove by examples to the contrary, though the felsitic structure is nowhere, I believe, so marked as at Y Graig; but if it were so, my case is not materially affected. If felsite is converted into a typical gneiss at $\mathrm{Y}$ Graig, all primá-facie objection to such a change disappears, and the fieldevidence receives important confirmation.

C. Callaway.

TeWkESBURY.

May 11, 1897.

TRINUCLEUS SETICORNIS AND THE UPPER BALA BEDS.

Str,- In the report of a discussion of a paper on the fauna of the Keisley Limestone, Part II (Q J.G.S., vol. liii, p. 106), the author is stated to have made the following remark: "Mr. Marr . . . . denied that Trinucleus seticornis was specially characteristic of Upper Bala beds, though some years ago he had called the Upper Bala beds of the Haverfordwest area after that fossil." I should hardly have supposed that my words required an explanation, but as the speaker on that occasion appeared puzzled, I will give it.

Mr. T. Roberts and I (in 1885) called the Upper Bala beds of Haverfordwest Trinucleus seticornis beds, because the fossil or one of its varieties is particularly abundant in those beds in that area, and we did not there discover it in beds of Middle Bala (Caradoc) age. We were perfectly justified in our action, and there is precedent for it ; e.g., no one supposes that the Leda myalis beds of the Cromer Forest Group are the only beds with Leda myalis. If we had spoken of the beds as constituting the zone of Trinucleus seticornis an explanation might be necessary, although I hold that even that 